\title{
Site-Specific 32P-Labeling of Cytokines, Monoclonal Antibodies, and Other Protein Substrates for Quantitative Assays and Therapeutic Application
}

\author{
William A. Clark1, Lara Izotova ${ }^{1,2}$, Doranelly Philipova ${ }^{1}$, Wei Wu ${ }^{2,3}$, Lei Lin ${ }^{2,4}$, and Sidney Pestka ${ }^{1,2}$ \\ ${ }^{1}$ PBL Biomedical Laboratories, Piscataway, NJ; ${ }^{2}$ Department of Molecular Genetics, Microbiology, and Immunol- \\ ogy, Robert Wood Johnson Medical School-UMDNJ, Piscataway, NJ; ${ }^{3}$ Department of Biomedical Science, Uni- \\ versity of California - Riverside, Riverside, CA; and ${ }^{4}$ Department of Physical Medicine and Rehabilitation, \\ JFK/Johnson Rehabilitation Institute, Edison, NJ, USA
}

\section{ABSTRACT}

Radiolabeled proteins are used in a variety of laboratory applications as well as in radioimmunotherapy. This review focuses on methods that utilize genetic engineering to introduce exogenous phosphorylation sites into proteins. Protein kinase substrate sites can be introduced into target proteins to serve as tags for several purposes. Because many protein kinases, each preferring a unique consensus sequence, are well characterized, the essential structure and function of the target protein can be effectively preserved through judicious selection and design of the phosphate incorporation site. After phosphorylation, these proteins are often indistinguishable from the parent molecules in assays of functional or biological activity. This convenient approach permits incorporation of ${ }^{32} P, 33 P, 35 S$, or nonradioactive ${ }^{31} \mathrm{P}$, and is rapid, efficient, and safe. Most importantly, $32 \mathrm{P}$ labeling of monoclonal antibodies or other therapeutic protein candidates has several significant advantages over radioiodination or chemical conjugation of heavy metal isotopes.

\section{INTRODUCTION}

Radiolabeled proteins have proven to be increasingly valuable in a wealth of applications. These range from basic biology and biochemistry (e.g., delineation of protein-protein interactions, protein-DNA, and protein-RNA interactions), to application to human disease (e.g., pharmacokinetics, diagnostic imaging, and radiotherapy). In the field of protein-protein interactions alone, radiolabeled proteins are essential tools in assessing antigen-antibody affinities, receptor-ligand interactions, receptor internalization and degradation, and expression cloning of receptors. In the laboratory setting, 125I is often the tag of choice for rapidly labeling proteins to high radiospecific activity. However, the risks and drawbacks of radioiodination are well known. Because iodinated proteins undergo dehalogenation, thyroid gland monitoring of lab personnel is required. The highenergy $\gamma$ emission of 125 I necessitates increased protective measures including lead shielding. Furthermore, iodination is a random process occurring throughout the protein chain, resulting in a heterogeneous population of labeled proteins. In fact, iodi- nation typically results in significant loss of activity of the target protein, an effect that has been particularly well documented in the case of monoclonal antibodies.

To circumvent the multiple drawbacks of iodination, we sought to develop a gentler, site-specific, high radiospecific activity labeling procedure that would allow the bulk of protein bioactivity to be retained. Secondly, we set out to use an isotope with a better safety profile than that of radioactive iodine. We decided upon enzymatic phosphorylation through engineered kinase sites as this approach avoids, in theory, many of the complications inherent in iodination and in chemical conjugation of heavy metal isotopes. Both the vector construction and subsequent labeling procedures using analogs of ATP are convenient and rapid and can be applied to a variety of protein targets.

Our initial work in this area focused on modification of interferons for use in receptor binding experiments $(47,82,88)$. When human interferon $\alpha \mathrm{A}$ was used as a model and re-engineered to contain kinase substrate domains, neither immunoreactivity nor biological activity was adversely affected, either in the presence or absence of the phosphate label. These results suggested that this approach could yield novel radioligands suitable for radioimmunoassays, ligand-binding studies, and possibly pharmacokinetic evaluation. Subsequently, we modified several other cytokines and monoclonal antibodies, and have now begun to evaluate the therapeutic potential of some of these molecules.

The engineering and labeling procedures were validated for cAMP-dependent protein kinase (PKA) $(47-49,82,88)$, casein kinase I (52), casein kinase II (51), and Src tyrosine kinase (Src) (50) sites. Two overall strategies became immediately evident: attachment or insertion of a kinase domain tag to the $\mathrm{N}$ or $\mathrm{C}$ terminus or internal to the target protein, or minor modification of endogenous sequences in the protein to yield a kinase substrate site. The latter approach is further enabled by the availability of different kinase sites allowing the insertion of acidic (casein kinase I and II), basic (PKA), or neutral (Src) residues as needed in order to minimally modify the target protein. That is, the engineering of the phosphorylation site can be optimized to have the minimum impact on the $\mathrm{pI}$ and hydrophobicity of the 
protein such that tertiary and quaternary structure and general pharmacokinetic properties are preserved.

For applications such as radioimmunotherapy, a number of isotopes commonly have been coupled to tumor-specific monoclonal antibodies, thus increasing their lethality to tumor cells. In addition to iodination with $131 \mathrm{I}$, chelation of heavy metal isotopes such as ${ }^{90} \mathrm{Y},{ }^{67} \mathrm{Cu}$, and ${ }^{188} \mathrm{Re}$ have each been examined for therapeutic monoclonal labeling. However, immunogenicity of therapeutic monoclonal antibodies often limits their therapeutic potential $(21,76)$, a concern that arises with any chemical conjugation procedure. Whereas the insertion of kinase substrate site into a monoclonal can maintain the essential quaternary structure of the molecule, chemical conjugations of iodine, peptides, or chelators are inherently damaging processes. Neither iodination chemistry nor chemical coupling of chelating agents or peptides is site specific. These reactions then yield multiple new epitopes on the resultant antibody bearing any of these radiolabels. Therefore, the therapeutic potential of these agents is compromised, particularly with regard to re-administration upon which the immune system could rapidly eliminate the protein from the circulation. The strategy of chemically conjugating PKA-phosphorylatable peptides to a larger protein (18) is remarkably similar to the standard coupling approach used to make peptide-specific antisera. Clearly, the peptide presents a new epitope, as does the linkage site to the larger protein. The immunogenicity of the larger protein is also exacerbated by peptide linkage (11).

Non-site-specific conjugation chemistries such as iodination also adversely affect specificity of the monoclonals for the tur mor-specific antigens, possibly through derivitization of amino acid side chains at or proximal to the complementarity/specificity determining regions necessary for antigen recognition. In addition, the risk of free iodine concentrating in patient or healthcare worker thyroids, stomachs, and salivary glands also instigated our pursuit of the phosphorylation approach. The use of engineered kinase sites, while conferring some potential for immunogenicity, appears to have significant advantages in preparing radiolabeled proteins for therapeutic application. This approach leaves largely intact the general structure of the target protein and permits selection of a specific kinase to minimize the impact of sequence mutations on protein function.

\section{PROTEIN KINASE REACTIONS}

The transfer of phosphate from the $\gamma$ phosphate of ATP or other nucleoside triphosphates to an acceptor amino acid can be accomplished by a variety of phosphotransferase enzymes. Protein-serine/threonine and protein-tyrosine kinases have been particularly well characterized, although other amino acid side chains can also be phosphorylated by specific protein kinases $(26,27)$. Many of these transferases are highly efficient in vitro, displaying attractive $\mathrm{K}_{\mathrm{m}}, \mathrm{k}_{\mathrm{cat}}$, and turnover numbers. Although ectokinases are less well characterized, they may prove to be attractive reagents for this purpose as these enzymes have been found to be released from neutrophils (77) and on the surface of T-lymphocytes (73), suggesting that the substrate sites for these kinases may possess low immunogenicity.

Because of their wide availability and extensive literature base, protein-serine/threonine and protein-tyrosine kinases and their substrates will be the focus of this review. These kinases transfer the $\gamma$ phosphate or sulfate from ATP or ATP $\gamma$ S or their analogs, and thus can be used to label proteins with radioactive 32P, 33P, 35S, or nonradioactive $31 \mathrm{P}$. The longer half-life of $35 \mathrm{~S}$ (87 days) may provide advantages in the laboratory setting, although the low energy beta emission is insufficient for therapy. The physical half-life (14.2 days) and energetic beta emission (mean $695 \mathrm{keV}$ ) of ${ }^{32} \mathrm{P}$ are appealing properties in term of therapeutic use with monoclonal and other protein substrates. If higher radiospecific activity is warranted, multiple phosphorylation sites or cassettes can be incorporated into the expression vector. In contrast, multiple iodination of single protein molecules would significantly increase the risk of protein inactivation in the conjugation reaction. For those applications such as pharmacokinetics where radioactivity may not be warranted, ${ }^{31}$ P-labeled proteins can be followed by phosphotyrosine-, phosphothreonine-, and phosphoserine-specific antibodies or by straightforward mass spectroscopy.

As mentioned above, two methods are immediately apparent for introducing kinase substrate sites into target proteins: fusion and site-specific mutation. In either case, access of the kinase to the recognition motif is a consideration such that surface epitopes or tail epitopes are typically the preferred sites on which to design the addition of a phosphate. One may also consider the potential impact of an introduced phosphate if inserted at or proximal to known regions of protein-protein interaction. In fact, the demonstration of an effect of phosphorylation within such a region on a well-characterized protein contact interface may yield new information on the dynamics of that interaction. Depending on the intended use of the modified protein, phosphorylation consensus sequences or cassettes can be fused to the $\mathrm{N}$ or $\mathrm{C}$ terminus or inserted internally within the protein. Alternatively, near-consensus site homologies within the target protein can be exploited through the site-specific mutation approach. That is, it is often possible to construct a new phosphorylation site within the protein through mutation of just one or a few amino acids. These manipulations are easily performed through standard genetic engineering techniques.

We used the technique of site-specific mutation to introduce phosphorylation sites into the amino acid sequences of a number of interferons $(47,48,82)$ (also R. Donnelly and S. Pestka, unpublished data for IL-2; W. Wu and S. Pestka, unpublished data for monoclonal antibody chCC49-WW5). The fusion approach was also useful for a variety of proteins and kinase sites $(1,3-7,9$, 15,19,28,32,33,36,49-52,59,60,62,63,68,74,81,83,85,86,88): interferon (88), monoclonal antibodies (49-52), retinoblastoma protein (1,32), osteopontin (4), c-Fos, (5), calmodulin (15), diphtheria toxin (59), endothelial growth factors (59), enterotoxins, (59) lymphokines (59), ricin (19,59), antibody fragments $(62,63)$, microtubule associated protein (81), Escherichia coli RNA polymerase $\beta^{\prime}$ and $\sigma$ subunits $(3,6)$, green fluorescent protein (85), E. coli TraT-RHO surface protein fusion (7), bacteriophage T4 primase (28), erythropoietin (68), opioid receptor peptide ligands (36), interleukin receptor subunit extracellular domains (83), IL-3 (C. Miyamoto, personal communication), interferon $\beta$ (X.-X. Zhou, J. Langer, and S. Pestka, unpublished data), IL-10, vIL-10, and cmvIL-10 (L. Izotova, S. Kotenko, S. Saccani, and S. Pestka, unpublished observations). Where exam- 


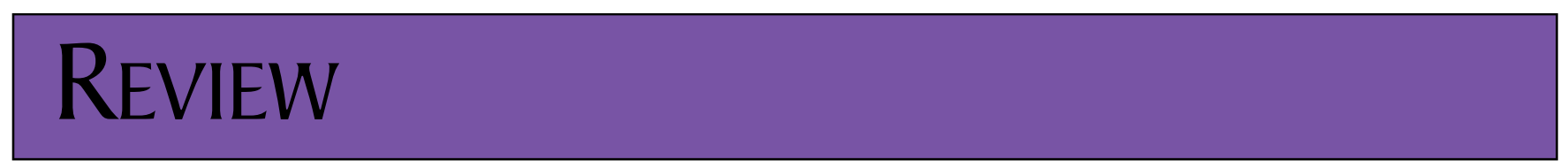

ined, the activities of the modified and phosphorylated proteins were, in most cases, virtually indistinguishable.

Another approach developed by Foxwell et al. (18) introduced a kinase recognition site into a peptide that was then covalently linked to a monoclonal antibody. Whereas the phosphorylated monoclonal was stable in serum, proteins modified by this method would have limited potential in vivo as this approach appears to favor the generation of a heterogeneous product carrying multiple new epitopes, thus enhancing antigenicity.

\section{PROTEIN KINASE SUBSTRATE SITES}

Consensus phosphorylation sequences have been identified and reported for a wide variety of kinases. We have successfully used four kinases to date by way of the recognition sequences shown in Table 1 that were based on the expansive kinase literature (for examples, see References 13,20,25,34,39,53,56-58, $64,87)$. Because protein serine/threonine kinases show significant differences in $\mathrm{K}_{\mathrm{m}}$ for serine vs. threonine (35), we utilized only serine as the phosphate acceptor to take advantage of the higher efficiency of this phosphotransferase reaction.

\section{PROTEINS WITH INTRODUCED PHOSPHORYLA- TION CONSENSUS SEQUENCES}

Our initial reports demonstrated that gentle phosphate labeling of interferons was not detrimental to protein structure or function $(47,82,88)$. Binding and crosslinking studies were carried out using phosphate-labeled human interferon (IFN) $\alpha$ A, $\alpha B 2$, and $\alpha A / D(2,10,16,47,66,78,82,88)$. A number of groups have followed similar procedures to introduce phosphorylation sites into a variety of proteins (Table 2). Blanar et al. (5) designed an expression vector to encode proteins with amino terminal extensions containing a cAMP-dependent protein kinase (PKA) recognition site. This region was fused to the leucine zipper dimerization motif of c-Fos that was then used to screen a cDNA library. The protein-protein interactions of the phosphorylated protein were then examined. Kaelin et al. (32) used the vector prepared by Blanar et al. (5) to prepare a $32 \mathrm{P}$-labeled glutathione S-transferase (GST)-retinoblastoma (pRB) fusion protein for efficient screening of expression libraries. Continuing these studies, Adams et al. (1) determined the region of $\mathrm{pRB}$ phosphorylated by cyclin A-cdk2 and cyclin E-cdk2. Ron and Dressler (74) constructed an expression vector similar to that of Blanar et al. (5) and Kaelin et al. (32). The vector encoded a GST tag and a PKA site that could be fused to target proteins. The 32P-labeled fusion protein could be used to identify interacting proteins. Stofko-Hahn et al. (81) constructed a vector with a PKA site, a Factor Xa cleavage site, and a calmodulinbinding peptide. Fusion proteins could easily be purified on a calmodulin affinity matrix and the fused protein phosphorylated with $\left[\gamma_{-} 32 \mathrm{P}\right]$ ATP and PKA. Chen and Hai (9) designed an $E$. coli expression vector with two tandem repeats of the heart muscle kinase consensus sequence and $\mathrm{a} \mathrm{His}_{6}$ tag designed to express fusion proteins for protein-protein interaction studies. Similarly, Kelman et al. (33) constructed E. coli expression vectors encoding a PKA substrate domain fused to hemagglutinin influenza
Table 1. Recognition Sites for Various Protein Kinases

\begin{tabular}{|c|c|}
\hline Protein Kinase & Recognition Site \\
\hline $\begin{array}{l}\text { AMP-dependent } \\
\text { otein kinase (PKA) }\end{array}$ & \\
\hline $\mathrm{Ca}$ & $\begin{array}{l}\text { spAspAspAspSerlleAspAspAsp- } \\
\text { spAspSer }\end{array}$ \\
\hline Casein kinase II & SerGluGluAsp \\
\hline Src ty & $\begin{array}{l}\text { eGluGluGlyThrTyr- } \\
\text { s }\end{array}$ \\
\hline \multicolumn{2}{|c|}{$\begin{array}{l}\text { Note: For introduction of the cAMP-dependent protein ki- } \\
\text { nase recognition site, we used ArgArgXaaSerXab where } \\
\text { Xaa is usually Ala and Xab has been Val, Leu, Met, or Gln } \\
(47-49,82) \text {. However, as shown previously, a wide variety } \\
\text { of amino acids can substitute for Xaa and Xab effectively } \\
(2,35,66,78,84) \text {. For the casein kinase I site, we used two } \\
\text { AspAspAspAspSer sequences in tandem, connected with } \\
\text { lleAsp shown in boldface (52) based on sequences report- } \\
\text { ed by Meggio et al. (58). For the casein kinase II site, we } \\
\text { used ( } 51) \text { the sequence shown }(2,34,61,65,67) \text {. For the } \\
\text { Src tyrosine kinase site, we used the sequence shown (50) } \\
\text { based on the sequence reported }(8,50) \text {. }\end{array}$} \\
\hline
\end{tabular}

virus epitope (HA) and $\mathrm{His}_{6}$ tags. This enabled fusion proteins to be concentrated by immunoprecipitation, purified on metal affinity chromatography, and labeled with isotope using the respective tags. Useful substrates for a number of kinases were constructed by Yang et al. (85) as fusion construct with green fluorescent protein (GFP). This work yielded a particularly efficient substrate for Src tyrosine kinase. To study the binding and engulfment of bacteria by BHK21 cells, Chang and Lo (7) fused a PKA substrate site onto the E. coli outer membrane lipoprotein TraT fused with snake venom rhodostomin (RHO) and a thrombin cleavage site. The fusion protein was expressed on the bacterial surface and could be radiolabeled by PKA. Surface-radiolabeled bacteria then permitted the development of a rapid, high sensitivity quantitative assay of bacterial binding to and internalization by BHK21 cells. Jing et al. (28) fused heart muscle kinase to the $\mathrm{N}$ or $\mathrm{C}$ terminus of the gp61 primase subunit of the bacteriophage T4-coded primosome. The fusions were then evaluated for phosphorylation in the presence or absence of single stranded DNA. Single-stranded DNA (ssDNA) protected both the $\mathrm{N}$ - and C-terminal fusions from phosphorylation, suggesting that a specific interaction of these regions with ssDNA shielded the phosphorylation sites from the protein kinase. Kinase protection was further enhanced as more components of the primosome were included in the assay.

Ashkar et al. (4) prepared a fusion protein with osteopontin containing a kinase recognition site and GST to study function and posttranslational modifications of mammalian osteopontin. Moss et al. (60) prepared fusion proteins with the intracellular domains of the $\gamma$-aminobutyric acid type A (GABAA) receptor to determine the recognition sites for PKA and protein kinase $\mathrm{C}$ 
Table 2. Proteins Labeled by Incorporation of Phosphorylation Sites

\begin{tabular}{|c|c|c|}
\hline Protein & Protein Kinase Site & References \\
\hline Human IFN- $\alpha \mathrm{A}$ & PKA & 47,88 \\
\hline Human IFN- $\alpha B 2$ & PKA & 82 \\
\hline Human IFN- $\alpha A / D$ & PKA & 82 \\
\hline Human IFN- $\beta$ & PKA & X.-X. Zhao, J. Langer, and S. Pestka, unpublished data \\
\hline Bovine IFN- $\tau$ & PKA & 2 \\
\hline Human IL-2 & PKA & R. Donnelly and S. Pestka, unpublished \\
\hline Human IL-3 & PKA & C. Miyamoto, personal communication \\
\hline Human IL-10 & PKA & L. Izotova, S. Kotenko, S. Saccani, and S. Pestka, unpublished data \\
\hline vIL-10, cmvIL-10 & PKA & L. Izotova, S. Kotenko, S. Saccani, and S. Pestka, unpublished data \\
\hline c-Fos & PKA & 5 \\
\hline Glutathione S-transferase & PKA & $4,15,32,74$ \\
\hline Retinoblastoma protein & PKA & 32 \\
\hline Calmodulin & PKA & 15 \\
\hline Calmodulin binding peptide & PKA & 81 \\
\hline Osteopontin & PKA & 4 \\
\hline$\gamma$-Aminobutyric acid receptor $A$ & PKA & 60 \\
\hline Dopamine receptors & PKA & 86 \\
\hline E. coli RNA polymerase $\beta^{\prime}$ subunit & PKA & 3,6 \\
\hline E. coli RNA polymerase $\sigma$ subunit & PKA & 3,6 \\
\hline \multirow[t]{3}{*}{ SV40 large T-antigen } & PKA & 84 \\
\hline & Casein kinase II & \\
\hline & Syclin-dependent kinas & \\
\hline Antibody fragments & Casein kinase II & 62 \\
\hline Ricin A chain & PKA & 19,59 \\
\hline $\begin{array}{l}\text { Diphtheria toxin amino terminal } \\
\text { fragments }\end{array}$ & PKA & 59 \\
\hline Ricin A/diphtheria toxin hybrid & PKA & 59 \\
\hline Toxic shock syndrome toxin I & PKA & 59 \\
\hline $\begin{array}{l}\text { Vascular endothelial growth factor } \\
\text { isoforms }\end{array}$ & PKA & 59 \\
\hline Anti-TAG-72 monoclonal antibody & PKA & 48,49 \\
\hline Anti-TAG-72 monoclonal antibody & Casein kinase I & 52 \\
\hline Anti-TAG-72 monoclonal antibody & Casein kinase II & $51,61,62$ \\
\hline Anti-TAG-72 monoclonal antibody & Src tyrosine kinase & 50 \\
\hline \multirow[t]{5}{*}{ Green fluorescent protein } & PKA & 85 \\
\hline & Src tyrosine kinase & \\
\hline & c-Abl & \\
\hline & Protein kinase $\mathrm{A}$ & \\
\hline & Protein kinase $C \beta \|$ & \\
\hline E. coliTraT-RHO hybrid & PKA & 7 \\
\hline $\begin{array}{l}\text { Bacteriophage T4-coded primase } \\
\text { (gp61) }\end{array}$ & Heart muscle kinase & 28 \\
\hline $\begin{array}{l}\text { Anti-CEA single chain monoclonal } \\
\text { antibody }\end{array}$ & PKA & 63 \\
\hline Erythropoietin & & 68 \\
\hline Enkaphalin and deltorphin & PKA & 36 \\
\hline $\begin{array}{l}\text { IL-1 receptor and IL-2 receptor } \alpha \text { subunit } \\
\quad \text { extracellular domains }\end{array}$ & PKA & 83 \\
\hline \multicolumn{3}{|c|}{$\begin{array}{l}\text { Note: Phosphorylation sites were introduced into various proteins as shown. PKA, cAMP-dependent protein kinase; IFN, interferon; } \\
\text { IL, interleukin; vIL-10, the viral homologue of human IL-10; CEA, carcinoembryonic antigen. }\end{array}$} \\
\hline
\end{tabular}


(PKC). Similarly, Zamanillo et al. (86) used fusion proteins of the dopamine receptor subtypes to study their phosphorylation by PKA and PKC. Xiao et al. (84) constructed fusion proteins with recognition sites for PKA, casein kinase II, and the cyclindependent kinase cdc2. This group demonstrated that nuclear import of SV 40 large tumor antigen fusion proteins, normally regulated by the motif comprising phosphorylation sites for casein kinase II and the cyclin-dependent kinase cdc2, could be controlled by PKA if the PKA recognition site is substituted for the casein kinase II site. Fischer et al. (15) constructed a vector that contained sequences encoding a FLAG epitope, GST, and a PKA recognition site, and fused these to the coding sequence of calmodulin. The 32P-labeled calmodulin fusion protein was used to identify calmodulin-binding proteins in cellular extracts to replace laborious techniques employing ${ }^{125} \mathrm{I}$-calmodulin or biotinylated calmodulin. Arthur and Burgess (3) and Burgess et al. (6) used $\mathrm{N}$-terminal $\mathrm{His}_{6}$-PKA fusions of $E$. coli RNA polymerase $\beta^{\prime}$ and $\sigma$ subunits to map the interaction site between one of the $\sigma$ subunits and the $\beta^{\prime}$ subunit of the core enzyme.

Neri et al. $(61,62)$ developed protein kinase tags for antibody fragments secreted from bacteria to identify immunoreactivity. After the fragments were labeled with $[\gamma-32 \mathrm{P}] \mathrm{ATP}$ and casein kinase II, the antibody fragments were used to determine affinity for specific antigens. These investigators concluded that "in contrast to non site-specific methods such as radioiodination, antibodies labeled with casein kinase II retain full immunoreactivity" (62). Patrick et al. (63) developed a 32P-labeled single chain monoclonal antibody against carcinoembryonic antigen (CEA). The labeled fusion construct showed selective toxicity and rapid internalization in LS-174T cells expressing high levels of CEA.

Mohanraj et al. (59) prepared an expression vector for introduction of a PKA site at the amino terminus of proteins. Seven different phosphorylatable proteins were prepared, demonstrating the generality of the methodology. After labeling with ${ }^{32} \mathrm{P}$, they concluded that "all seven proteins used in this study could be expressed with the phosphorylation sequence at their amino terminus and specifically labeled without loss of biological activity" (59). Erythropoietin bearing an N-terminal protein kinase domain was shown by Quelle et al. (68) to retain full receptor binding activity and biological activity in vitro, and could be used for receptor internalization studies. In contrast, C-terminal kinase substrate domain fusions failed to compete for receptor binding. Kieffer et al. (36) used a PKA tag fused to the $\mathrm{C}$ terminus of the delta opioid-selective peptides enkephalin and deltorphin to quantify affinity of these ligands for the receptor. Whitehorn et al. (83) fused the extracellular domains of the IL-1 receptor, IL-2 receptor, and E-selectin to a 3' PKA consensus sequence. After labeling with ${ }^{32} \mathrm{P}$ by PKA treatment, the fusion proteins competently bound their cognate ligands.

\section{PURIFICATION OF MODIFIED PROTEINS}

Because the introduction of a carefully designed phosphorylation site usually does not materially alter the structure or physical characteristics of the target protein, the same procedures used for purifying the unmodified protein have been found to be effective prior to phosphorylation $(47-52,82,88)$.

\section{PHOSPHORYLATION OF PROTEINS BY PKA}

To attain high levels of labeling, [32P]ATP should be used at the highest specific activity available. This radiolabel is supplied in aqueous (0.01 M Tricine) buffer. The entire contents of the vial are dried in a SpeedVac ${ }^{\circledR}$ (Thermo Savant, Holbrook, NY, USA) and the residue dissolved in a minimal volume of water to the final concentration denoted below. The catalytic subunit of the cAMP-dependent protein kinase from bovine heart is used for the reaction illustrated below using a monoclonal antibody MAb-ch-CC49-6P and MAb-ch-CC49-KI.

MAb-ch-CC49-6P is labeled with [ $\gamma_{-}-32$ P]ATP and PKA as described previously (49). Approximately $10 \mu \mathrm{g}$ of the monoclonal were incubated at $30^{\circ} \mathrm{C}$ for $60 \mathrm{~min}$ with $0.5 \mathrm{mCi}$ of $[\gamma-$ 32P]ATP (specific activity of $6000 \mathrm{Ci} / \mathrm{mmol}$; DuPont-NEN, Boston, MA, USA) and 25 units of the catalytic subunit of bovine heart muscle PKA (specific activity of $>$ or $=20000$ units $/ \mathrm{mg}$ [Sigma, St. Louis, MO, USA]; dissolved in $6 \mathrm{mg} / \mathrm{mL}$ DTT) in $25 \mu \mathrm{L}$ of $20 \mathrm{mM}$ Tris- $\mathrm{HCl}, \mathrm{pH} 7.4,100 \mathrm{mM} \mathrm{NaCl}$, and $12 \mathrm{mM} \mathrm{MgCl}_{2}$, then cooled on ice to stop the reaction. Af ter addition of $300 \mu \mathrm{L}$ of $5 \mathrm{mg} / \mathrm{mL}$ bovine serum albumin in 10 $\mathrm{mM}$ sodium pyrophosphate, $\mathrm{pH} 6.7$ at $4^{\circ} \mathrm{C}$, the $0.325 \mathrm{~mL}$ reaction mixture was dialyzed against 1000 volume of phosphatebuffered saline (PBS) overnight at $4^{\circ} \mathrm{C}$. Dialysis buffer was changed twice. Incorporation of radioactivity into the monoclonal antibody was measured with a liquid scintillation spectrometer after precipitation of the protein with trichloroacetic acid (TCA) (65). To remove labile ${ }^{32} \mathrm{P}$, the final product in $0.325 \mathrm{~mL}$ was adjusted to $\mathrm{pH} 7.4$ with $1 \mathrm{M}$ Tris base, then incubated at $37^{\circ} \mathrm{C}$ overnight. The labeled material was then stored in a liquid nitrogen freezer in small aliquots until use.

After the reaction, the samples were dialyzed as noted previously. However, alternative methods for removal of free phosphate and ATP can be used, such as centrifugal filter separators or disposable gel filtration columns. Although all of these procedures are effective, we found that dialysis is the simplest and most effective method. It should be noted that we also observed two rates of phosphate release (48-52). One was the rapid release reflecting loosely bound phosphate with the major attached phosphate being relatively stable. When this is observed, we carry out the overnight dialysis at $37^{\circ} \mathrm{C}$ rather than at $4^{\circ} \mathrm{C}$. As expected, autoradiography shows that the final phosphorylated product comigrates with the corresponding Coomassie blue-stained protein band upon polyacrylamide electrophoresis. When fusion proteins containing epitope tags such as FLAG, Myc, HA, or GST are used, the protein can be isolated on beads bearing an antibody or ligand with high affinity for these tags. After washing the beads, phosphorylation of the protein can be performed in situ on the bead-immobilized protein. After washing to eliminate free kinase, nucleotide, $32 \mathrm{P}$, and other contents of the reaction mix, phosphorylated proteins can be released from the affinity column by elution with free affinity ligand or by acidification.

It is common for this procedure to yield protein products having very high radiospecific activity, often at the level of 5000 $\mathrm{Ci} / \mathrm{mmol}$. The specific activity is further raised by inserting more than one phosphorylation site cassette into the target protein (49). Additional specific reagents and further details on these procedures are described elsewhere (67). 


\section{PHOSPHORYLATION OF PROTEINS BY CASEIN KINASE I}

MAb-chCC49CKI was labeled with $\left[\gamma_{-32}{ }^{32}\right]$ ATP and casein kinase I as described (52). Approximately $10 \mu \mathrm{g}$ of the monoclonal were incubated at $37^{\circ} \mathrm{C}$ for $60 \mathrm{~min}$ with $0.5 \mathrm{mCi}$ of $[\gamma-$ 32P]ATP (specific activity of $6000 \mathrm{Ci} / \mathrm{mmol}$ ) and 15 units of casein kinase I (Upstate Biotechnology, Waltham, MA, USA; Cat. No. 14-112) in $25 \mu \mathrm{L}$ of $50 \mathrm{mM}$ Tris- $\mathrm{HCl}, \mathrm{pH} 7.5,100 \mathrm{mM}$ $\mathrm{NaCl}$, and $12 \mathrm{mM} \mathrm{MgCl}_{2}$, then cooled on ice to stop the reaction. After addition of $300 \mu \mathrm{L}$ of $5 \mathrm{mg} / \mathrm{mL}$ bovine serum albumin in $10 \mathrm{mM}$ sodium pyrophosphate, $\mathrm{pH} 6.7$ at $4^{\circ} \mathrm{C}$, the 0.325 $\mathrm{mL}$ reaction mixture was dialyzed against 1000 volumes of $\mathrm{PBS}$ overnight at $4^{\circ} \mathrm{C}$. Dialysis buffer was changed twice. Incorporation of radioactivity into the monoclonal antibody was measured with a liquid scintillation spectrometer after precipitation of the protein with TCA (65). To remove labile ${ }^{32} \mathrm{P}$, the final product was preincubated at $37^{\circ} \mathrm{C}$ for $24 \mathrm{~h}$ in the medium in which it was to be used or in $\mathrm{pH} 7.4$ buffer such as PBS. As noted above, this procedure was established because it was apparent that a percentage of the $[32 \mathrm{P}]$ phosphate attached to the protein was labile and could be eliminated by this preincubation (48-52).

\section{PHOSPHORYLATION OF PROTEINS BY CASEIN KINASE II}

MAb-chCC49CKII was labeled with [ $\left.\gamma^{3}{ }^{32} \mathrm{P}\right] \mathrm{ATP}$ and casein kinase II as described (51). Approximately $10 \mu \mathrm{g}$ of the monoclonal were incubated at $30^{\circ} \mathrm{C}$ for $60 \mathrm{~min}$ with $0.5 \mathrm{mCi}$ of $[\gamma-$ $\left.{ }^{32} \mathrm{P}\right] \mathrm{ATP}$ (specific activity of $6000 \mathrm{Ci} / \mathrm{mmol}$ ) and $1 \mu \mathrm{L}(0.23$ units) of casein kinase II (Upstate Biotechnology, Cat. No. 14197) in $25 \mu \mathrm{L}$ of $20 \mathrm{mM}$ Tris- $\mathrm{HCl}, \mathrm{pH} 7.4,100 \mathrm{mM} \mathrm{NaCl}$, and

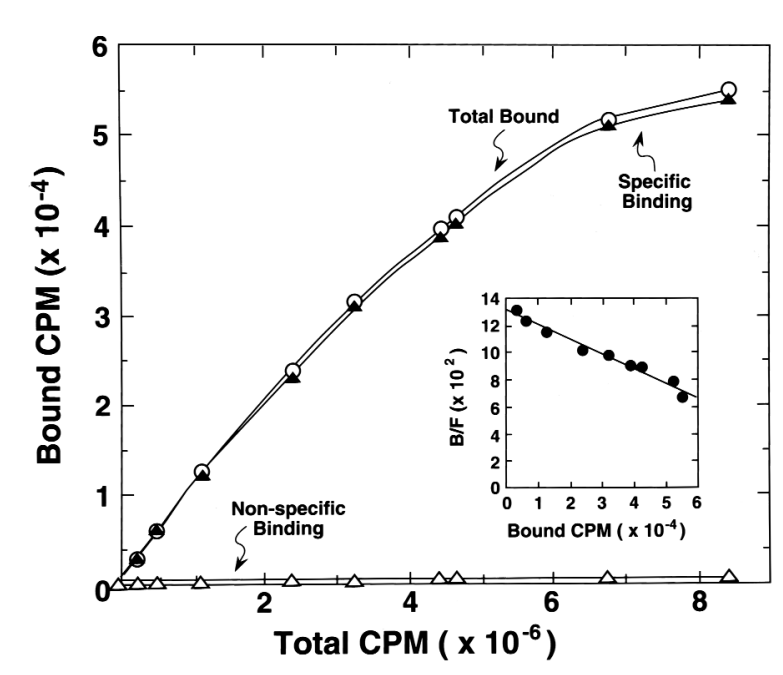

Figure 1. Binding of monoclonal antibody chCC49K1 to MCF-7 4C10 breast carcinoma cells. Labeling of chCC49K1 monoclonal antibody and binding to MCF-7 4C10 cells were performed as described in the text (49). Nonspecific binding values were subtracted from total bound counts to obtain specific bound counts shown on the ordinate. Reproduced, by permission of the publisher, from Lin et al. (49).
$12 \mathrm{mM} \mathrm{MgCl}_{2}$, then cooled on ice to stop the reaction. After addition of $300 \mu \mathrm{L}$ of $5 \mathrm{mg} / \mathrm{mL}$ bovine serum albumin in $10 \mathrm{mM}$ sodium pyrophosphate, $\mathrm{pH} 6.7$ at $4^{\circ} \mathrm{C}$, the $0.325 \mathrm{~mL}$ reaction mixture was dialyzed against 1000 volumes of PBS overnight at $4^{\circ} \mathrm{C}$. Dialysis buffer was changed twice. Incorporation of radioactivity into the monoclonal antibody was measured with a liquid scintillation spectrometer after precipitation of the protein with TCA (65). To remove labile $32 \mathrm{P}$, the final product was preincubated at $37^{\circ} \mathrm{C}$ for $24 \mathrm{~h}$ in the medium in which it was to be used or in $\mathrm{pH} 7.4$ buffer such as PBS. As noted above, this procedure was established because it was apparent that a percentage of the $\left[{ }^{32} \mathrm{P}\right]$ phosphate attached to the protein was labile and could be eliminated by this preincubation (48-52).

\section{PHOSPHORYLATION OF PROTEINS BY SrC TYROSINE KINASE}

MAb-chCC49Tyr was labeled with [y-32P]ATP and casein kinase II as described (50). Approximately $10 \mu \mathrm{g}$ of the monoclonal were incubated at $30^{\circ} \mathrm{C}$ for $60 \mathrm{~min}$ with $0.5 \mathrm{mCi}$ of $[\gamma-$ 32P]ATP (specific activity of $6000 \mathrm{Ci} / \mathrm{mmol}$ ) and 15 units of $\mathrm{Src}$ tyrosine kinase (Src kinase, P60 c-src; Upstate Biotechnology, Cat. No. 14-117) in $25 \mu \mathrm{L}$ of $50 \mathrm{mM}$ Tris-HCl, $\mathrm{pH} 7.0$, and 50 $\mathrm{mM} \mathrm{MgCl} 2$, then cooled on ice to stop the reaction. After addition of $300 \mu \mathrm{L}$ of $5 \mathrm{mg} / \mathrm{mL}$ bovine serum albumin in $10 \mathrm{mM}$ sodium pyrophosphate, $\mathrm{pH} 6.7$ at $4^{\circ} \mathrm{C}$, the $0.325 \mathrm{~mL}$ reaction mixture was dialyzed against 1000 volumes of PBS overnight at $4^{\circ} \mathrm{C}$. Dialysis buffer was changed twice. Incorporation of radioactivity into the monoclonal antibody was measured with a liquid scintillation spectrometer after precipitation of the protein with TCA (65). To remove labile $32 \mathrm{P}$, the final product was preincubated at $37^{\circ} \mathrm{C}$ for $24 \mathrm{~h}$ in the medium in which it was to be used or in $\mathrm{pH} 7.4$ buffer such as PBS. As noted above, this procedure was established because it was apparent that a percentage of the $\left[{ }^{32} \mathrm{P}\right]$ phosphate attached to the protein was labile and could be eliminated by this preincubation (48-52).

\section{BINDING OF 32P-LABELED MONOCLONAL ANTI- BODIES TO CELL SURFACE ANTIGENS}

Binding of [32P]MAb-chCC49KI and [32P]MAb-chCC49$6 \mathrm{P}$ to MCF-7 4C10 human breast carcinoma cells was performed as described (49). MCF-7 4C10 cells used for binding studies were grown to confluence in 6-well tissue culture plates in medium (DMEM; GIBCO/Invitrogen, Grand Island, NY, USA) supplemented with $10 \%$ fetal bovine serum, $0.05 \mathrm{mg} / \mathrm{mL}$ sodium pyruvate, $0.005 \mathrm{mg} / \mathrm{mL}$ insulin, $0.5 \times$ nonessential amino acids, and treated with 1000 units $/ \mathrm{mL}$ human interferon $\gamma$ for $48 \mathrm{~h}$ prior to assay. Twenty minutes before assay, the medium was removed, and $1 \mathrm{~mL}$ of fresh medium was added to each well. Then [32 P] MAb-chCC49KI was added with or without a 100-fold excess of unlabeled MAb-chCC49KI or MAbchCC49. Following incubation at room temperature for $1 \mathrm{~h}$, the plates were washed four times with $2 \mathrm{~mL}$ of ice-cold PBS to remove the unbound radioactive ligand. One milliliter of $1 \%$ sodium dodecyl sulfate (SDS) was added to each well to remove cells and the bound 32P-labeled monoclonal. Radioactivity 
bound by the cells was determined in a liquid scintillation counter by placing the $1 \mathrm{~mL}$ sample in $5 \mathrm{~mL}$ of scintillation fluor. Binding of [32P]MAb-chCC49-6P to MCF-7 4C10 cells was determined similarly with the exception that the cells were cultured in 96-well plates since the radiospecific activity of this monoclonal was greater than that of [32P] MAb-chCC49KI.

The binding of the monoclonal antibodies to TAG-72 antigen on the MCF-7 4C10 breast cancer cell line is shown in Figure 1. [ $\left.{ }^{32} \mathrm{P}\right] \mathrm{MAb}-\mathrm{chCC} 49 \mathrm{KI}$ bound to MCF-7 4C10 cells treated with 1000 units/mL human interferon $\gamma$ with specific binding approaching saturation at the higher concentrations of antibody tested. Scatchard analysis (75) of the data indicated that these cells have 1900 receptors per cell as calculated by the binding of [32 $\mathrm{P}] \mathrm{MAb}-\mathrm{chCC} 49 \mathrm{KI}$. The binding of [ $\left.{ }^{32} \mathrm{P}\right] \mathrm{MAb}-$ chCC49KI to the cells was blocked by the addition of unlabeled MAb-chCC49KI. The binding of [32P]MAb-chCC49-6P to this cell line (data not shown) was similar to that of [ $\left.{ }^{32} \mathrm{P}\right] \mathrm{MAb}-$ chCC49KI. It is noteworthy that specific binding was very nearly identical to total binding when using these $32 \mathrm{P}$-labeled monoclonals. This result was initially surprising when compared to results with ${ }^{125} \mathrm{I}$-labeled proteins. It is fortuitous that once this is demonstrated for a particular binding assay/monoclonal pair, 32P-labeled proteins can often be studied without competitor, thus saving significant amounts of expensive and difficult to obtain unlabeled protein. However, in developing a binding assay, control experiments need to be performed to determine whether nonspecific binding is a significant contributor to total binding.

\section{BINDING OF 32P-LABELED INTERFERON TO CELL STRUCTURE RECEPTORS}

The binding of $32 \mathrm{P}$-labeled human IFN $\alpha \mathrm{B} 2$ and IFN $\alpha \mathrm{A} / \mathrm{D}$ to bovine MDBK cells and human Daudi cells is shown in Figure 2. Again, it can be noted that specific binding is nearly identical to total binding for each of these interferons on each cell line. We hypothesize that the extremely low nonspecific binding is largely conferred by the gentle enzymatic labeling of the monoclonals, as well as the labeling of the antibodies at highly specific sites. Depending on the labeling procedure, chemical labeling of proteins occurs on random lysine or tyrosine residues. This random labeling can inactivate a portion of the protein molecules, often resulting in denaturation of the protein and thus contributing to the higher nonspecific labeling seen in radioiodinated proteins. Another contributor to the higher nonspecific binding observed with iodination is that the iodine atom is large and nonpolar, and effectively enhances nonspecific hydrophobic interactions. Furthermore, chemical labeling results in a mixed population of derivitized molecules having the label attached at a variety of locations along the protein chain.

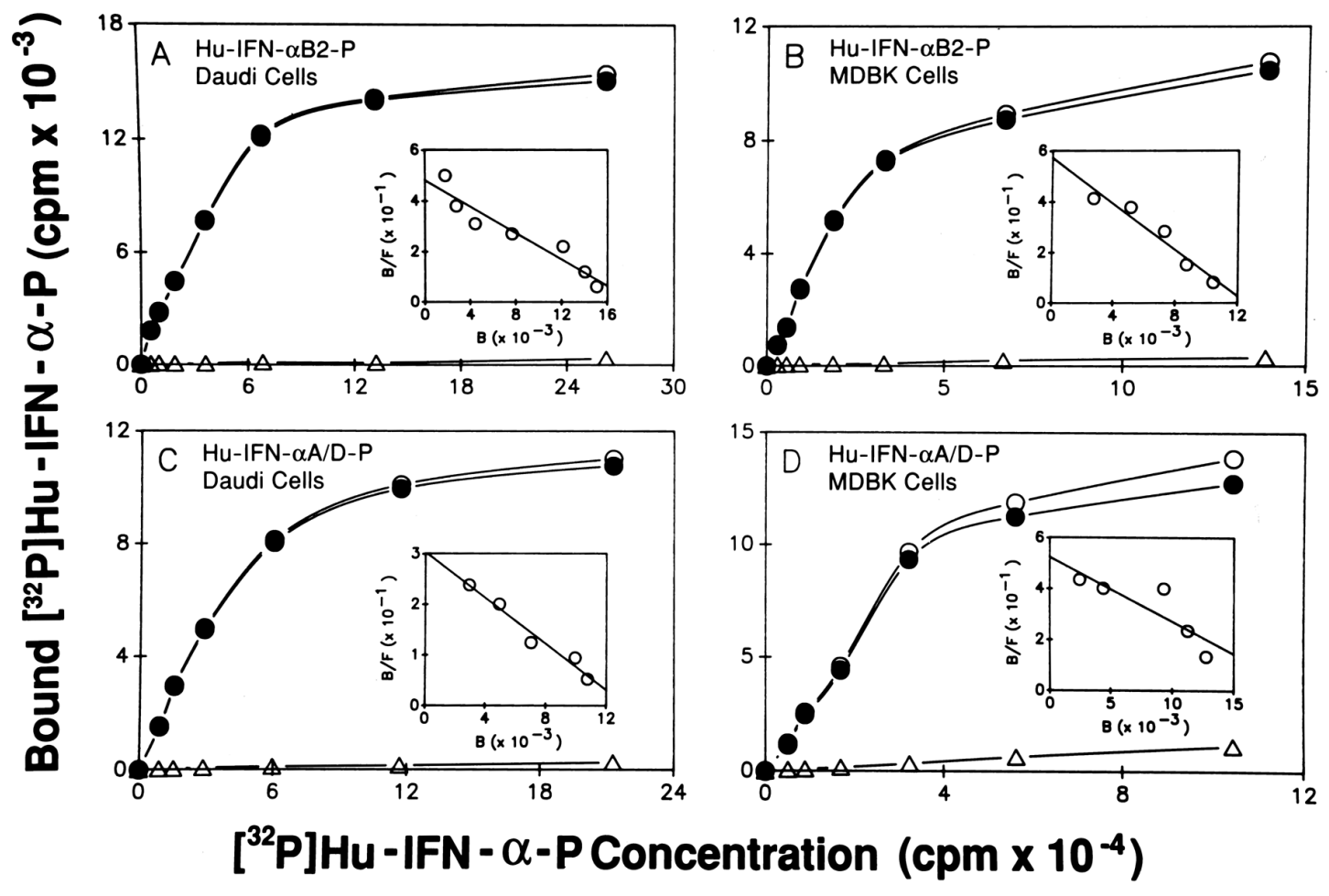

Figure 2. Binding of 32P-labeled human IFN- $\alpha \mathrm{B} 2$ and human IFN- $\alpha \mathrm{A} / \mathrm{D}$ to cells. $32 \mathrm{P}-\mathrm{Hu}-\mathrm{IFN}-\alpha \mathrm{B} 2$ or $32 \mathrm{P}-\mathrm{Hu}-\mathrm{IFN}-\alpha \mathrm{A} / \mathrm{D}$ was added to cells at the indicated concentrations in the absence (total binding, open circles) or presence (nonspecific binding, open triangles) of excess nonradioactive $\mathrm{Hu}-\mathrm{IFN}-\alpha \mathrm{B} 2$ or $\mathrm{Hu}-\mathrm{IFN}-\alpha \mathrm{A} / \mathrm{D}$, respectively, and incubated for $1 \mathrm{~h}$ at $24^{\circ} \mathrm{C}$. Specific binding (filled circles) represents the difference between the total and the nonspecific binding. (A and B) Binding of 32P-Hu-IFN- $\alpha$ B2 to human Daudi and Bovine MDBK cells, respectively; (C and D) binding of $32 \mathrm{P}-\mathrm{Hu}-\mathrm{IFN}-\alpha \mathrm{A} / \mathrm{D}$ to Daudi and MDBK cells, respectively. (Inset) Scatchard analysis of the specific binding data (B, radioactivity of ligand bound to cells; F, radioactivity of free or unbound ligand). Reproduced, by permission of the publisher, from Wang et al. (82). 
Site-specific labeling of proteins via kinase site insertion circumvents these drawbacks of random chemical conjugation. Furthermore, the availability of different protein kinases permits conservation of positive, negative, or neutral charge and contributes to retaining the activity of the protein.

\section{STABILITY OF PHOSPHORYLATED PROTEINS}

As noted above, some phosphorylated proteins exhibit two rates of radiophosphate loss, a rapid rate and a relatively slow rate of loss of "stable phase" phosphate (Figure 3). When this rapid rate is seen, incubating the phosphorylated product at $37^{\circ} \mathrm{C}$ during the dialysis procedure for about $24 \mathrm{~h}$ eliminates the rapid decay phase (Figure 4). The percentage of [ $\left.{ }^{32} \mathrm{P}\right]$ phosphate retained on the MAb at different intervals was compared to the initial value in either buffer or various sera (Figure 4). Approximately $93 \%-96 \%$ of the radiophosphate remained attached to the MAb after $24 \mathrm{~h}$ incubation in buffer, fetal bovine serum, human serum, or mouse serum.

\section{MOLECULAR MODELING TO DESIGN APPROPRI- ATE SITES OF PHOSPHATE INTRODUCTION}

Because the crystal structures of many proteins are known, it is possible to use the coordinates of the crystal structure to eval-

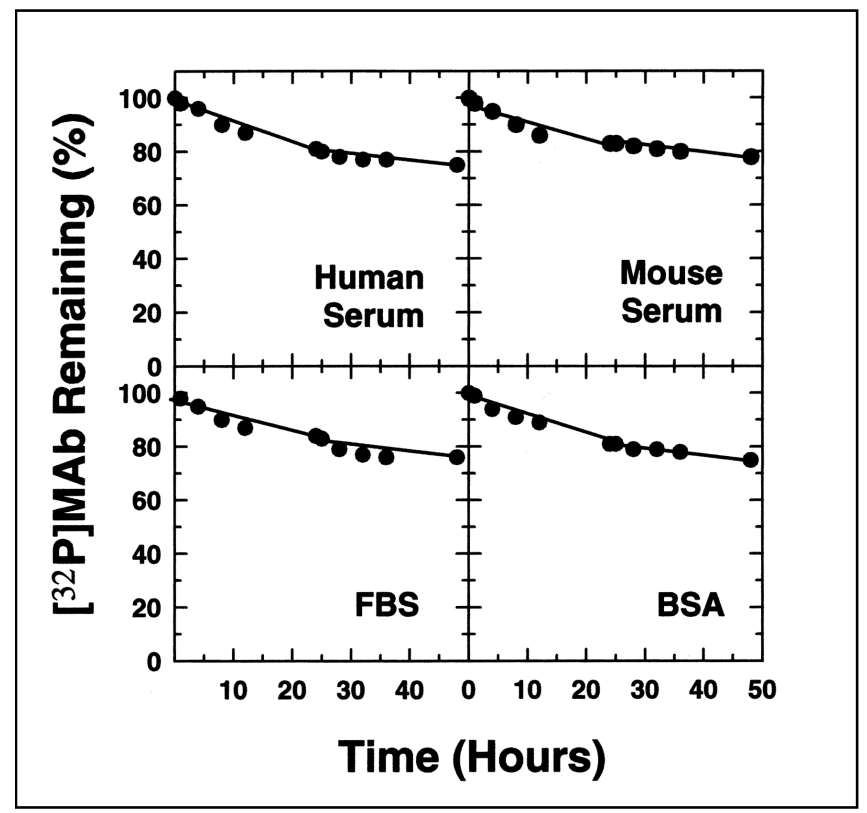

Figure 3. Stability of [ $\left.{ }^{32} \mathrm{P}\right] \mathrm{MAb}-\mathrm{chCC} 49 \mathrm{CKI}$ in the absence of the preincuba tion step. Each reaction contained $0.5 \mathrm{~mL}$ of human serum, mouse serum, fetal bovine serum, or a solution of bovine serum albumin $(5 \mathrm{mg} / \mathrm{mL}$ in PBS); 125 $\mathrm{mL}$ of $1 \mathrm{M}$ Tris-HCl, $\mathrm{pH} 7.4$, and $15 \mathrm{~mL}$ of [ $\left.{ }^{32} \mathrm{P}\right] \mathrm{MAb}$-chCC49CKI $\left(1.1 \times 10^{7}\right.$ $\mathrm{cpm}$ ), for a total volume of $0.64 \mathrm{~mL}$, and was incubated to $37^{\circ} \mathrm{C}$. Aliquots of 20 $\mathrm{mL}$ were taken in duplicate over a $48 \mathrm{~h}$ period to determine the stability of the [22 $\mathrm{P}$ ]phosphate attached to the MAb. The percentage of ${ }^{32} \mathrm{P}$ remaining on the [22 P]MAb-chCC49CKI in sera and buffer at various time points is shown. Experiments were performed as described in the text except that no preincubation step was used to remove loosely attached phosphate after the phosphorylation reaction. Data from Lin et al. (52). uate the effects of the insertion of the phosphorylation site and the phosphate itself. We have been able to utilize molecular modeling very effectively to predict useful sites within a protein in which to introduce phosphorylation sites with minimal modification of the protein structure (W. Wu and S. Pestka, unpublished results). Figure 5 illustrates the molecular model of MAbchCC49-6P and delineates the six phosphorylation sites fused to the C-terminus of each heavy chain. We have found this structural prediction approach to be particularly useful in the design of phosphorylation sites internal to the protein of interest and in the optimization of the phosphate local milieu to strongly enhance the stability of the radiolabel on the target protein (W. Wu and S. Pestka, unpublished results).

\section{SPECIFIC APPLICATION OF 32P-LABELED PROTEINS AND MONOCLONAL ANTIBODIES TO TUMOR RADIOIMMUNOTHERAPY}

The clinical potential of monoclonal antibodies has begun to be exploited such that MAbs specific for human tumor antigens are currently used in the clinical setting, and a large number of novel antibodies are in various stages of human trials. Although MAbs can act via complement- or cell-mediated toxicity, some MAbs, such as Herceptin and Rituxan, are used directly without radiolabeling or conjugation to cytotoxic agents with sufficient efficacy to gain FDA approval. However, it is believed that the ef ficacy of these MAbs could be markedly improved so that each is being radiolabeled with 131 I or heavy metal isotopes for testing. A number of other radiolabeled antibodies are under development such as a second generation anti-TAG-72 antibody, CC49, and derivatives directed at a human tumor antigen expressed in number of human carcinomas including breast, colon, ovarian, stomach, endometrial, pancreatic, and lung cancers.

A radiolabeled MAb may display greater antitumor efficacy than the unlabeled counterpart because the radiolabel can be

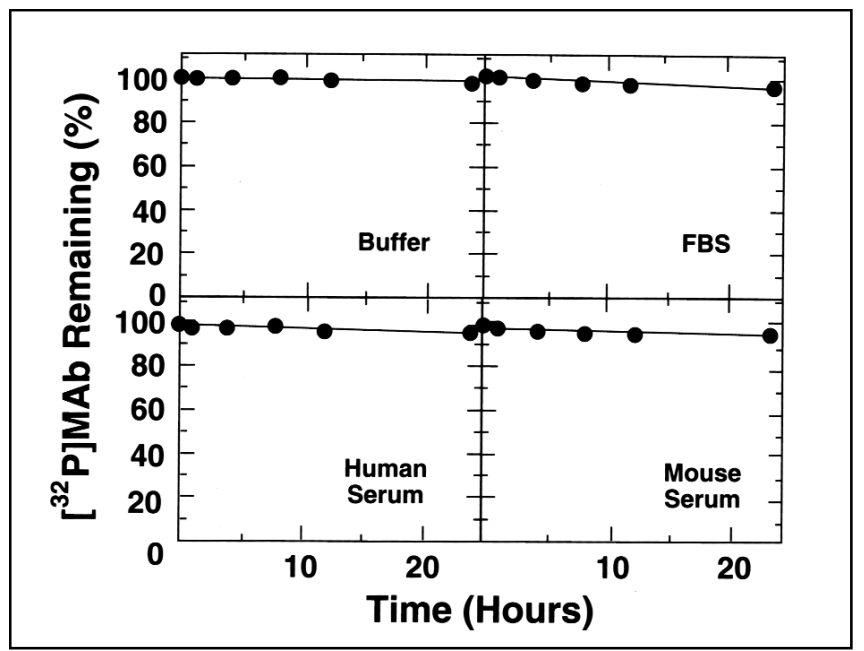

Figure 4. Stability of [32P]MAb-chCC49KI in various sera. Labile phosphate was removed before use of the labeled monoclonal antibody as described in the text. The percentage of 32P remaining on the [32P]MAb-chCC49KI in sera and buffer at various time points is shown. Experiments were performed as described in the text. Data from Lin et al. (49). 
lethal to cells within a radius of at least a few cell diameters around the cell to which the antibody has bound. Thus, surrounding tumor cells can be irradiated, even if expression of the tumor antigen on these cells is poor. Furthermore, in contrast to antibody-toxin conjugates, the efficacy of the radiolabel is independent of antibody internalization.

However, the drawbacks of radioiodination or chelation of heavy metal isotopes to MAbs include loss of specificity of the antibody for target antigen, and generation of a mixed population of MAb species potentially leading to increased immunogenicity. The remarkable advantages of phosphorylation with ${ }^{32} \mathrm{P}$ are readily apparent from the data presented herein and previously $(47-52,82,88)$. These advantages include virtually quantitative retention of specific immunoreactivity of antibody molecules, a homogeneous population of MAb species imparting lower overall immunogenicity, and a high energy $\beta$ emission which exhibits excellent tissue absorption to a maximum radius of approximately $10 \mathrm{~mm}$ enhancing the percentage of total radiation delivered locally to the tumor.

A further significant advantage of $32 \mathrm{P}$ has been documented in recent years. The longer half life of this isotope imparts a greater margin of safety in patients than isotopes such as ${ }^{131} \mathrm{I}$ and many of the heavy metals such as ${ }^{111} \mathrm{In},{ }^{99} \mathrm{mTc},{ }^{90} \mathrm{Y}$, and ${ }^{186} \mathrm{Re}$ used for monoclonal labeling. Short-lived radionucleotides often yield low initial dose rates such that only 3 logs or less of cancer cells can be killed out of the approximately 10 logs required for tumor elimination (17). Longer half-life isotope-bearing MAbs deliver greater tumor doses of radiation and have significantly lower adverse effects in bone marrow, i.e., to hematopoietic progenitor cells. Specifically, a comparison of MAbs labeled with ${ }^{64} \mathrm{Cu}$ and ${ }^{67} \mathrm{Cu}$ found that the difference in half-life between these two isotopes is responsible for the significantly higher therapeutic index of the

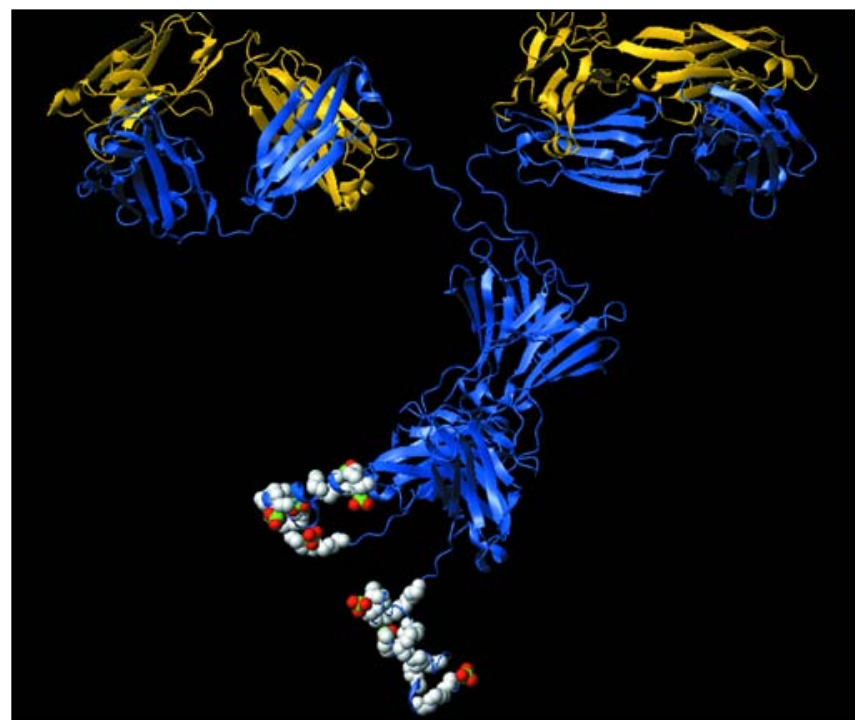

Figure 5. Model of MAb-chCC49-6P with six phosphorylation sites. Six phosphorylation sites were attached to the $\mathrm{C}$ terminus of the heavy chain of MAb chCC49 as described (49). The light chains are shown in yellow whereas the heavy chains are shown in royal blue. The white regions shown in the space-filting models represent the regions where the protein kinase recognition sites were introduced. The green regions, barely visible, represent the phosphates attached to the serine residues after phosphorylation. Oxygens attached to the phosphates are shown in red. monoclonal bearing ${ }^{67} \mathrm{Cu}$, the longer-lived isotope (12). In the case of $32 \mathrm{P}$, with the same tumoricidal dose, $32 \mathrm{P}$-labeled antibody results in 30\% lower bone marrow exposure to radiation than the same antibody coupled to ${ }^{90} \mathrm{Y}(24)$. An additional concern with chelating agents that are used to attach heavy metal isotopes is the development of antibodies to the chelating agent in almost all patients, resulting in serum sickness in about $40 \%$ of patients, a problem avoided with the use of $32 \mathrm{P}$. The in vitro success of a $32 \mathrm{P}-$ labeled CEA-directed single chain monoclonal in cell culture experiments is encouraging (36). If this efficacy can be extended into human clinical trials, phosphorylated monoclonals may well provide a new weapon in the fight against any number of cancers.

In addition to monoclonal antibodies, this technique can be utilized to enhance the efficacy of other potential protein therapeutic strategies. Because the significant molecular size of MAbs often limits their penetrance into tumors, small protein ligands are attractive therapeutic molecules when coupled to toxins or radiolabels. For instance, one well characterized tumor antigen associated with breast and ovarian cancers is the epidermal growth factor (EGF) receptor. EGF receptor peptide antagonists bearing radiophosphate may be exciting candidate molecules for treating such cancers.

\section{CONCLUDING REMARKS}

We have described various applications of this procedure for labeling proteins that do not inherently contain phosphorylation sites. However, a variety of proteins have phosphorylation sites that can be phosphorylated directly. For instance, we have used IFN- $\gamma$, phosphorylated on the endogenous PKA site quite effectively as a ligand $(14,16,22,23,29-31,37,38,40-46,54,55,69-72$, $79,80)$. The procedures described in this review provide protein substrates that are conveniently labeled to high radiospecific activity and which are normally as active biologically as the parent molecules. The binding specificity of these proteins is high enough that use of excess competitor to establish nonspecific binding can be largely eliminated. Proteins can be labeled with phosphate or sulfate at slightly modified internal sequences in the protein or on segments added as fusions. This technique also may provide a greater margin of safety for laboratory personnel as well as hospital workers and patients subjected to the hazards of radioimmunotherapy. The therapeutic potential of $32 \mathrm{P}$-labeled proteins is starting to be recognized, and site-specific phosphorylation by kinases shortly will provide novel potential therapeutics.

\section{ACKNOWLEDGMENTS}

We thank Stephen Gillies, Jeffrey Schlom, and Bruce Daugherty for their input and advice on many stages of these projects, and Nicole Corveleyn and Ellen Feibel for assistance in preparation of the manuscript. These studies were supported in part by USPHS Grants RO1-CA46465 from the National Cancer Institute, RO1-AI36450 from the National Institute of Allergy and Infections Diseases, and Small Business Innovation Research Grant 1R43CA86568-01 from the National Institutes of Health. A special award from the Milstein Family Foundation to S.P. provided additional support for a variety of efforts in these projects. 


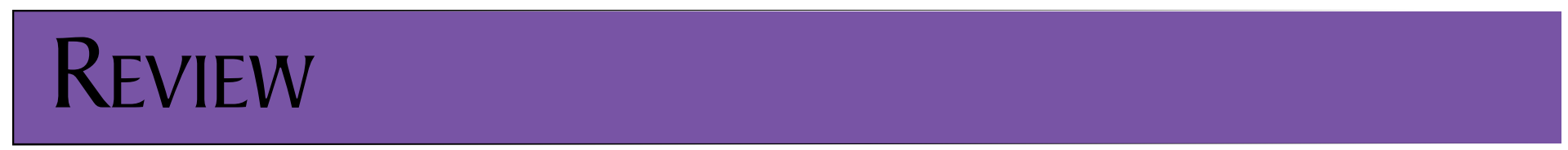

\section{REFERENCES}

1.Adams, P.D., X. Li, W.R. Sellers, K.B. Baker, X. Leng, J.W. Harper, Y. Taya, and W.G.J. Kaelin. 1999. Retinoblastoma protein contains a C-terminal motif that targets it for phosphorylation by cyclin-cdk complexes. Mol. Cell Biol. 19:1068-1080.

2.Alexenko, A.P., J. Li, N. Mathialagan, L. Izotova, T.M. Mariano, S. Pestka, and R.M. Roberts. 1995. Interaction of bovine interferon- $\tau$ with the type I interferon receptor on Daudi cells. J. Interferon Cytokine Res. 15:S97.

3.Arthur, T.M. and R.R. Burgess. 1998. Localization of a $\sigma 70$ binding site on the $\mathrm{N}$ terminus of the Escherichia coli RNA polymerase $\beta^{\prime}$ subunit. J. Biol. Chem. 273:31381-31387.

4.Ashkar, S., D.B. Teplow, M.J. Glimcher, and R.A. Saavedra. 1993. In vitro phosphorylation of mouse osteopontin expressed in E. coli. Biochem. Biophys. Res. Commun. 191:126-133.

5.Blanar, M.A. and W.J. Rutter. 1992. Interaction cloning: identification of a helix-loop-helix zipper protein that interacts with c-Fos. Science 256:10141018.

6.Burgess, R.R., T.M. Arthur, and B.C. Pietz. 2000. Mapping protein-protein interaction domains using ordered fragment ladder far-Western analysis of hexahistadine-tagged protein fusions. Methods Enzymol. 328:141-157.

7.Chang, H. and S.J. Lo. 2000. Modification with a phosphorylation tag of PKA in the TraT-based diplay vector of Echerichia coli J. Biotechnol. 78:115122.

8.Cheng, H.C., H. Nishio, O. Hatase, S. Ralph, and J.H. Wang. 1992. A synthetic peptide derived from $\mathrm{p} 34 \mathrm{cdc} 2$ is a specific and efficient substrate of src-family tyrosine kinases. J. Biol. Chem. 267:9248-9256.

9.Chen, B.P. and T. Hai. 1994. Expression vectors for affinity purification and radiolabeling of proteins using Escherichia coli as host. Gene 139.73-75.

10.Cook, J.R., C.M. Cleary, T.M. Mariano, L. Izotova, and S. Pestka. 1996. Differential responsiveness of a splice variant of the human type I interferon receptor to interferons. J. Biol. Chem. 271:13448-13453.

11.Dagan, S., E. Tzehoval, M. Fridkin, and M. Feldman. 1987. Tuftsin and tuftsin conjugates potentiate immunogenic processes: effects and possible mechanisms. J. Biol. Response Mod. 6:625-636.

12.DeNardo, G.L., D.L. Kukis, S. Shen and S.J. DeNardo. 1996. Accurate measurement of copper-67 in the presence of copper-64 contaminant using a dose calibrator. J. Nucl. Med. 37:302-306.

13.Edelman, A.M., D.K. Blumenthal, and E.G. Krebs. 1987. Protein serine/ threonine kinases. Annu. Rev. Biochem. 56:567-613.

14.Fields, R., T.M. Mariano, S. Stein, and S. Pestka. 1987. Recombinant rat and murine immune interferons are phosphorylated at a single site, Ser132. J. Interferon Res. 8:549-557.

15. Fischer, R., Y. Wei, and M. Berchtold. 1996. Detection of calmodulin-binding proteins using a ${ }^{32} \mathrm{P}$-labeled GST-calmodulin fusion protein and a novel renaturation protocol. BioTechniques 21:292-296.

16.Flores, I., T.M. Mariano, and S. Pestka. 1991. Human interferon omega $(\omega)$ binds to the alpha/beta receptor. J. Biol. Chem. 266:19875-19877.

17.Fowler, J.F. 1990. Radiological aspects of low dose rates in radioimmunotherapy. Int. J. Radiat. Oncol. Biol. Phys. 18:1261-1269.

18.Foxwell, B.M., H.A. Band, J. Long, W.A. Jeffery, D. Snook, P.E. Thorpe, G. Watson, P.J. Parker, et al. 1988. Conjugation of monoclonal antibodies to a synthetic peptide substrate for protein kinase: a method for labelling antibodies with 32P. Br. J. Cancer 57:489-493.

19.Fryxell, D., B.Y. Li, D. Mohanraj, B. Johnson, and S. Ramakrishnan. 1995. Genetic construction of a phosphorylation site in ricin A chain: specific radiolabeling of recombinant proteins for localization and degradation studies. Biochem. Biophys. Res. Commun. 210.253-259.

20.Glass, D.B. and E.G. Krebs. 1980. Protein phosphorylation catalyzed by cyclic AMP-dependent and cyclic GMP-dependent protein kinases. Annu. Rev. Pharmacol. Toxicol. 20:363-388.

21.Goldenberg, D.M. 1993. Monoclonal antibodies in cancer detection and therapy. Am. J. Med. 94:297-312.

22.Hibino, Y., T.M. Mariano, C.S. Kumar, C.A. Kozak, and S. Pestka. 1991. Expression and reconstitution of a biologically active mouse interferon gamma receptor in hamster cells: chromosomal location of an accessory factor. J. Biol. Chem. 266:6948-6951.

23.Hibino, Y., C.S. Kumar, T.M. Mariano, D. Lai, and S. Pestka. 1992. Chimeric interferon gamma receptors demonstrate that an accessory factor required for activity interacts with the extracellular domain. J. Biol. Chem. 267:3741-3749

24. Howell, R.W., S.M. Goddu, and D.V. Rao. 1998. Proliferation and the ad- vantage of longer-lived radionuclides in radioimmunotherapy. Med. Phys. 25:37-42.

25.Hunter, T. and J.A. Cooper. 1985. Protein-tyrosine kinases. Annu. Rev. Biochem. 54:897-930.

26.Hunter, T. and B.M. Sefton. 1991. Protein Phosphorylation, Part A, Methods in Enzymology, p. 1-763.

27.Hunter, T. and B.M. Sefton. 1991. Protein Phosphorylation, Part B, Methods in Enzymology, p. 1-547.

28.Jing, D.H., F. Dong, G.J. Latham, and P.H. von Hippel. 1999. Interactions of bacteriophage T4-coded primase (gp61) with the T4 replication helicase (gp41) and DNA in primosome formation. J. Biol. Chem. 274:2728727298.

29. Jung, V., A. Rashidbaigi, C. Jones, J.A. Tischfield, T.B. Shows, and S. Pestka. 1987. Human Chromosomes 6 and 21 are required for sensitivity to human interferon gamma. Proc. Natl. Acad. Sci. USA 84:4151-4155.

30.Jung, V., C. Jones, A. Rashidbaigi, D.D. Geyer, H.G. Morse, R.B. Wright, and S. Pestka. 1988. Chromosome mapping of biological pathways by fluorescence-activated cell sorting and cell fusion: the human interferon gamma receptor as a model system. Somatic Cell and Mol. Genet. 14:583-592.

31.Jung, V., C. Jones, C.S. Kumar, S. Stefanos, S. O'Connell, and S. Pestka. 1990. Expression and reconstitution of a biologically active human interferon gamma receptor in hamster cells. J. Biol. Chem. 265:1827-1830.

32.Kaelin, W.G.J., W. Krek, W.R. Sellers, J.A. DeCaprio, F. Ajchenbaum, C.S. Fuchs, T. Chittenden, Y. Li, P.J. Farnham, and M.A. Blanar. 1992. Expression cloning of a cDNA encoding a retinoblastoma-binding protein with E2F-like properties. Cell 70:351-364.

33. Kelman, Z., N. Yao, and M. O'Donnell. 1995. Escherichia coli expression vectors containing a protein kinase recognition motif, His6-tag and a hemagglutinin epitope. Gene 166:177-178.

34.Kemp, B.E. and R.B. Pearson. 1990. Protein kinase recognition sequence motifs. Trends. Biochem. Sci. 15:342-346.

35.Kemp, B.E., D.J. Graves, E. Benjamini, and E.G. Krebs. 1977. Role of multiple basic residues in determining the substrate specificity of cyclic AMP-dependent protein kinase. J. Biol. Chem. 252:4888-4894.

36. Kieffer, B.L., D. Black, and C.G. Hirth. 1993. 32P-labeled opioid peptides with high affinity for the delta-opioid receptor. Anal. Biochem. 215:1-8.

37.Kotenko, S.V., L.S. Izotova, B.P. Pollack, T.M. Mariano, R.J. Donnelly, G. Muthukumaran, J.R. Cook, G. Garotta, et al. 1995. Interaction between the components of the interferon gamma receptor complex. J. Biol. Chem. 270.20915-20921.

38.Kotenko, S.V., L.S. Izotova, B.P. Pollack, G. Muthukumaran, K. Paukku, O. Silvennoinen, J.N. Ihle, and S. Pestka. 1996. Other kinases can substitute for Jak2 in signal transduction by IFN- $\gamma$. J. Biol. Chem. 271:1717417182.

39.Krebs, E.G. and J.A. Beavo. 1979. Phosphorylation-dephosphorylation of enzymes. Annu. Rev. Biochem. 48:923-959.

40.Kumar, C.S., T.M. Mariano, M. Noe, A.K. Deshpande, P.M. Rose, and S. Pestka. 1988. Expression of the murine interferon $\gamma$ receptor in Xenopus Laevis oocytes. J. Biol. Chem. 263:13493-13496.

41.Kumar, C.S., G. Muthukumaran, L.J. Frost, M. Noe, Y.-H. Ahn, T.M. Mariano, and S. Pestka. 1989. Molecular characterization of the murine interferon gamma receptor cDNA. J. Biol. Chem. 264:17939-17946.

42. Kung, H.-F. and E. Bekesi. 1986. Phosphorylation of human immune interferon (IFN- $\gamma$ ). Methods Enzymol. 119.296-301.

43.Langer, J. A., A. Rashidbaigi, V. Jung, H.-F. Kung, and S. Pestka. 1985. Identification of the receptor for immune interferon on human cell lines us ing 32P-labeled human immune interferon. International Society for Interferon Research, Clearwater Beach, FL, October, 1985.

44.Langer, J.A. and S. Pestka. 1985. Changes in binding of alpha interferon IFN- $\alpha$ A to HL60 cells during myeloid differentiation. J. Interferon Res. 5:637-649.

45.Langer, J.A., A. Rashidbaigi, and S. Pestka. 1986. Preparation of 32P-labeled murine immune interferon and its binding to the mouse immune interferon receptor. J. Biol. Chem. 21:9801-9804.

46.Langer, J.A. and S. Pestka. 1986. Procedures for studying binding of interferon to human cells in suspension cultures. Methods Enzymol. 119:305311 .

47.Li, B.L., J.A. Langer, B. Schwartz, and S. Pestka. 1989. Creation of phosphorylation sites in proteins: construction of a phosphorylatable human interferon alpha. Proc. Natl. Acad. Sci. USA 86:558-562.

48.Lin, L., B. Daugherty, J. Schlom, and S. Pestka. 1996. Construction of phosphorylatable monoclonal antibody to a tumor-associated antigen. Can- 
cer Res. 56:4250-4254.

49.Lin, L., S.D. Gillies, Y. Lan, L. Izotova, W. Wu, J. Schlom, and S. Pestka. 1998. Construction of phosphorylatable chimeric monoclonal antibody CC49. Int. J. Oncol. 13:115-120.

50.Lin, L., S.D. Gillies, J. Schlom, and S. Pestka. 1998. Construction of phosphorylatable chimeric monoclonal antibody CC49 with a tyrosine Src kinase recognition site. Int. J. Oncol. 13:725-732.

51.Lin, L., S.D. Gillies, J. Schlom, and S. Pestka. 1998. Construction of phosphorylatable monoclonal antibody CC49 with a casein kinase II recognition site. Anticancer Res. 18:3971-3978.

52.Lin, L., S.D. Gillies, J. Schlom, and S. Pestka. 1999. Construction of phosphorylatable chimeric monoclonal antibody CC49 with a casein kinase I recognition site. Protein Expr. Purif. 15:83-91.

53. Marchiori, F., F. Meggio, O. Marin, G. Borin, A. Calderan, P. Ruzza, and L.A. Pinna. 1988. Synthetic peptide substrates for casein kinase 2. Assessment of minimum structural requirements for phosphorylation. Biochim. Biophys. Acta 971:332-338.

54.Mariano, T.M., L. Izotova, and S. Pestka. 1994. Receptor binding studies, p. 77-91. In F.R. Balkwill (Ed.), Cytokines-A Practical Approach. IRL Press at Oxford University Press, Oxford.

55.Mariano, T.M., C.A. Kozak, J.A. Langer, and S. Pestka. 1987. The mouse immune interferon receptor gene is located on chromosome 10. J. Biol. Chem. 262:5812-5814.

56. Marin, O., F. Meggio, F. Marchiori, G. Borin, and L.A. Pinna. 1986. Site specificity of casein kinase-2 (TS) from rat liver cytosol. A study with model peptide substrates. Eur. J. Biochem. 160:239-244.

57. Marin, O., A. Calderan, P. Ruzza, G. Borin, F. Meggio, N. Grankowski, and F. Marchiori. 1990. Synthetic peptides including acidic clusters as substrates of yeast casein kinase-2. Int. J. Pept. Protein Res. 36:374-380.

58.Meggio, F., J.W. Perich, E.C. Reynolds, and L.A. Pinna. 1991. A synthetic beta-casein phosphopeptide and analogues as model substrates for casein ki nase-1, a ubiquitous, phosphate directed protein kinase. FEBS Lett. 283:303-306.

59.Mohanraj, D., J.L. Wahlsten, and S. Ramakrishnan. 1996. Expression and radiolabeling of recombinant proteins containing a phosphorylation motif. Protein Expr. Purif. 8:175-182.

60.Moss, S.J., C.A. Doherty, and R.L. Huganir. 1992. Identification of the cAMP-dependent protein kinase and protein kinase $\mathrm{C}$ phosphorylation sites within the major intracellular domains of the beta 1 , gamma $2 S$, and gamma $2 \mathrm{~L}$ subunits of the gamma-aminobutyric acid type A receptor. J. Biol. Chem. 267:14470-14476.

61.Neri, D., P.G. Natali, H. Petrul, P. Soldani, M.R. Nicotra, R. Vola, A. Rivella, A.M. Creighton, et al. 1996. Recombinant anti-human melanoma antibodies are versatile molecules. J. Invest. Dermatol. 107:164-170.

62.Neri, D., H. Petrul, G. Winter, Y. Light, R. Marais, K.E. Britton, and A.M. Creighton. 1996. Radioactive labeling of recombinant antibody fragments by phosphorylation using human casein kinase II and [gamma-32P]-ATP. Nat. Biotechnol. 14:485-490.

63.Patrick, M.R., K.A. Chester, and G.A. Pietersz. 1998. In vitro characterization of a recombinant $32 \mathrm{P}$-phosphorylated anti-(carcinoembryonic antigen) single chain antibody. Cancer Immunol. Immunother. 46:229-237.

64.Pearson, R.B. and B.E. Kemp. 1991. Protein kinase phosphorylation site sequences and consensus specificity motifs: tabulations. Methods Enzymol. 200.62-81.

65.Pestka, S. 1972. Studies in transfer ribonucleic acid-ribosome complex. J. Biol. Chem. 247:4669-4678.

66. Pestka, S. 1997. The interferon receptors. Semin. Oncol. 24(3 Suppl. 9):S918, S9-40.

67.Pestka, S., L. Lin, W. Wu, and L. Izotova. 2000. Use of phosphorylation tags in proteins. Methods Enzymol. 327:594-613.

68.Quelle, D.E., K.J. Lynch, R.E. Burkert-Smith, S. Weiss, W. Whitford, and D.M. Wojchowski. 1992. Phosphorylatable and epitope tagged human erythropoietins: utility and purification of native baculovirus-derived forms. Prot. Expr. Purif. 3:461-469.

69.Rashidbaigi, A., H.-F. Kung, and S. Pestka. 1985. Characterization of receptors for immune interferon in U937 cells with ${ }^{32}$ P-labeled human recombinant immune interferon. J. Biol. Chem. 260.8514-8519.

70.Rashidbaigi, A., H.-F. Kung, and S. Pestka. 1986. Binding of ${ }^{32}$ P-labeled human recombinant immune interferon to U937 cells. Methods Enzymol. 119.315-321.

71.Rashidbaigi, A., J.A. Langer, V. Jung, C. Jones, H.G. Morse, J.A. Tischfield, J.J. Trill, H.-F. Kung, and S. Pestka. 1986. The gene for the human immune interferon receptor is located on chromosome 6. Proc. Natl. Acad. Sci. USA 83:384-388.

72. Rashidbaigi, A., S. Stefanos, V. Jung, and J. Langer. 1988. Immune interferon receptor: chemical and enzymatic sensitivity. J. Interferon Res. 8:641654.

73. Redegeld, F.A., P. Smith, S. Apasov, and M.V. Sitkovsky. 1997. Biochim. Biophys. Acta 1328:151-165.

74. Ron, D. and H. Dressler. 1992. pGSTag - a versatile bacterial expression plasmid for enzymatic labeling of recombinant proteins [Erratum, BioTechniques 14:221, 1993]. BioTechniques 13:866-869.

75.Scatchard, G. 1949. Attraction of proteins for small molecules and ions. Ann. NY Acad. Sci. 51:660-672.

76.Schlom, J. 1995. Monoclonal antibodies in cancer therapy, p. 507-521. In V.T. Devita, S. Hellman, and S.A. Rosenberg (Eds.), Biological Therapy of Cancer. Lippincott, Philadelphia.

77.Skubitz, K.M., D.D. Ehresmann, and T.P. Ducker. 1991. Characterization of human neutrophil ecto-protein kinase activity released by kinase substrates. J. Immunol. 147:638-650.

78.Soh, J., T.M. Mariano, J.K. Lim, L. Izotova, O. Mirochnitchenko, B. Schwartz, J.A. Langer, and S. Pestka. 1994. Expression of a functional human type I interferon receptor in hamster cells: application of functional yeast artificial chromosome (YAC) screening. J. Biol. Chem. 269:1810218110.

79.Stefanos, S., Y.H. Ahn, and S. Pestka. 1989. Characterization of human interferon- $\gamma$ receptor purified from placenta. J. Interferon Res. 9:719-730.

80.Stefanos, S. and S. Pestka. 1990. A convenient assay for detection of soluble interferon receptors. J. Biol. Regul. Homeost. Agents 4:57-59.

81.Stofko-Hahn, R.E., D.W. Carr, and J.D. Scott. 1992. A single step purift cation for recombinant proteins. Characterization of a microtubule associated protein (MAP 2) fragment which associates with the type II cAMP-dependent protein kinase. FEBS Lett. 302:274-278.

82. Wang, P., L. Izotova, T.M. Mariano, R.J. Donnelly, and S. Pestka. 1994. Construction and activity of phosphorylatable human interferon-alpha B2 and interferon-alpha A/D [Erratum, J. Interferon Res. 14:97, 1994.]. J. Interferon. Res. 14:41-46.

83. Whitehorn, E.A., E. Tate, S.D. Yanofsky, L. Kochersperger, A. Davis, R.B. Mortensen, S. Yonkovich, K. Bell, et al. 1995. A generic method for expression and use of "tagged" soluble versions of cell surface receptors. Biotechnology 13:1215-1219.

84.Xiao, C.Y., S. Hubner, R.M.. Elliot, A. Caon, and D.A. Jans. 1996. A consensus cAMP-dependent protein kinase (PK-A) site in place of the $\mathrm{CcN}$ motif casein kinase II site simian virus 40 large $\mathrm{T}$-antigen confers PK-A-mediated regulation of nuclear import. J. Biol. Chem. 271:6451-6457.

85. Yang, F., Y. Liu, S.D. Bixby, J.D. Friedman, and K.M. Shokat. 1999. Highly efficient green fluorescent protein-based kinase subtrates. Anal. Biochem. 266.167-173.

86.Zamanillo, D., E. Casanova, A. Alonso-Llamazares, S. Ovalle, M.A. Chinchetru, and P. Calvo. 1995. Identification of a cyclic adenosine 3',5'monophosphate-dependent protein kinase phosphorylation site in the carboxy terminal tail of human D1 dopamine receptor. Neurosci. Lett. 188:183-186.

87.Zetterqvist, O. and U. Ragnarsson. 1982. The structural requirements of substrates of cyclic AMP-dependent protein kinase. FEBS Lett. 139:287290.

88.Zhao, X.X., B.L. Li, J.A. Langer, G. Van Riper, and S. Pestka. 1989. Construction and phosphorylation of a fusion protein $\mathrm{Hu}-\mathrm{IFN}$-alpha A/gamma. Anal. Biochem. 178:342-347.

\section{Address correspondence to:}

Dr. William A. Clark

PBL Biomedical Laboratories

131 Ethel Road West, Suite 6

Piscataway, NJ 08854-5900

e-mail: bclark@pblbio.com 